\title{
Influence of inflammatory response on infarct size and microvascular obstruction estimated by cardiac magnetic resonance in patients with ST-elevation myocardial infarction
}

\author{
Justyna Rajewska-Tabor ${ }^{1,2^{*}}$, Magorzata Pyda ${ }^{1,2}$, Anna Kociemba², Magdalena Janus ${ }^{1,2}$, Magdalena Lanocha ${ }^{1,2}$, \\ Andrzej Siniawski ${ }^{1,2}$
}

From 18th Annual SCMR Scientific Sessions

Nice, France. 4-7 February 2015

\section{Background}

The inflammatory response during ST-segment elevation myocardial infarction (STEMI) has been shown to influence the clinical outcome. Moreover, infarct size (IS) and microvascular obstruction (MVO) predict major adverse events in patients with STEMI.

The aim of the study was to compare the inflammatory response measured by $\mathrm{C}$-reactive protein (CRP) serum concentration and the number of white blood cells (WBC) with the infarct size and MVO estimated by CMR.

\section{Methods}

We examined 85 patients (mean age $59 \pm 11$ years; 59 males and 26 females) with acute STEMI. CRP and white blood cells were measured at the admission to the hospital. CMR examinations were performed on a $1.5 \mathrm{~T}$ scanner (Siemens, Avanto) using an eight-channel phased-array coil combined with 4-6 elements of spinal coil within 3 days after STEMI. Cine imaging with steady-state free precession and late gadolinium enhancement (LGE) were performed in the long axis and the contiguous short axis slices to evaluate myocardial function, IS and MVO. Infarct size was defined as an area greater than $50 \%$ of the maximal signal intensity within LGE (FWMH - full-width half maximum). MVO was diagnosed as an area of contrast hypoenhancement within the infarct zone and was included in the

I Cardiology Clinic, University of Medical Sciences in Poznan, Lusowo, Poland

Full list of author information is available at the end of the article assessment of IS. IS and MVO were determined by planimetry and a summation of discs method.

\section{Results}

The ejection fraction in the examined population was $54.5 \pm 10 \%$, infarct size: $24.57 \pm 20.79 \mathrm{~g}$ and MVO: $2.02 \pm 4.7 \mathrm{~g}$. WBC and CRP levels were measured at the admission to the hospital (WBC: $11.34 \pm 3.34 \mathrm{mld} / \mathrm{l}$ and CRP serum level: $21.58 \pm 26.2 \mathrm{mg} / \mathrm{dl})$. There were 27 patients with small ( $\leq 10 \%$ of myocardium) infarct size and 58 patients with bigger IS $(>10 \%)$. Despite a significant difference in ejection fraction in both groups $(60.33 \pm 7.79 \%$ and $51.75 \pm 9.98 \% ; \mathrm{p}=0.002$ ), no significant differences in the inflammatory response were noted in either of the groups. However, we observed a weak correlation between CRP serum level and infarct size $(\mathrm{p}=0.03 ; \mathrm{r}=0.23)$ and a stronger one between the leukocyte number and the infarct size $(\mathrm{p}=0.000004 ; \mathrm{r}=0.72)$. The number of WBC and the CRP serum level also correlated significantly with the size of MVO ( $\mathrm{p}=0.014 ; \mathrm{r}=0.45$ and $\mathrm{p}=0.0004 ; \mathrm{r}=0.69$ ).

\section{Conclusions}

Inflammatory response during STEMI influences infarct size and microvascular obstruction measured by CMR.

\section{Funding}

N/A.

\section{Authors' details}

'I Cardiology Clinic, University of Medical Sciences in Poznan, Lusowo, Poland. ${ }^{2}$ Magnetic Resonance Department, University of Medical Sciences in Poznan, Poznan, Poland. 
doi:10.1186/1532-429X-17-S1-P160

Cite this article as: Rajewska-Tabor et al:: Influence of inflammatory response on infarct size and microvascular obstruction estimated by cardiac magnetic resonance in patients with ST-elevation myocardial infarction. Journal of Cardiovascular Magnetic Resonance 2015 17(Suppl 1): P160.

Submit your next manuscript to BioMed Central and take full advantage of:

- Convenient online submission

- Thorough peer review

- No space constraints or color figure charges

- Immediate publication on acceptance

- Inclusion in PubMed, CAS, Scopus and Google Scholar

- Research which is freely available for redistribution

Submit your manuscript at www.biomedcentral.com/submit
C Biomed Central 